\title{
The Abominable Killer: An Introspection of the Bundy Murders; The Bundy Murders: A Comprehensive History
}

\author{
Jereena Babu
}

Department of English Studies, Christ (Deemed to be University), Bangalore, India

Received: 08 Nov 2020; Received in revised form: 09 Dec 2020; Accepted: 19 Dec 2020; Available online: 27 Dec 2020

(C)2020 The Author(s). Published by Infogain Publication. This is an open access article under the CC BY license

(https://creativecommons.org/licenses/by/4.0/).

\begin{abstract}
Crimes are not something that is hidden from the eyes of the public. But some crimes have their way of being kept secret from the eyes of those hunting down the ones behind this atrocity, namely serial killers. This would not be possible unless the murder was planned out in such a way that was undetectable by the police and for that to happen it was necessary that the person committing the murders had higherorder thinking skills and a unique way of planning a murder so clean and perfect. Ted Bundy, being the handsome heartthrob of many young women despite them knowing his background of killing spree is the main subject of this research paper and through the unveiling of his psychopathic pattern of crime and his pattern of victim choosing, the murders of one of the greatest serial killers of all time are studied and exposed to have a better understanding of what methodology worked through the criminal mastermind's head.
\end{abstract}

Keywords-Serial killer, Ted Bundy, young women, higher-order thinking skills, psychopathic.

The infamous serial killer of America made his entry into the world of nightmare for young women in the 1960s terrorizing them and at the same time also being widely popular and most wanted by young women even after they had heard of his infamous and heinous crimes in and around the city. No amount of sense could be knocked into the heads of these young girls who despite having witnessed and heard of his horrendous methods of killing girls of their age and practicing sexual acts with their corpses, were ready to understand what kind of danger they were dragging themselves into and that the absurd fantasy they were trying to build around and for him was something that should never have been fantasized in the first place. Theodore Ted Bundy isn't the serial killer kind where one would expect the killer to look the part of a killer, dressed shabbily, ragged features with the description of a person who is able to commit such monstrosities painted on his face rather he was quite the gentleman, with ocean blue eyes, a charm that drew women to him in a snap of a finger accompanied by an aura which befuddled women into thinking that he only ever had good intentions.
Killing women was nothing short of a psychotic fun activity for him where the thrill of abducting women in the hope of fulfilling his psychopathic sexual and homicidal fantasies was what kept him going and gave him that edge or the adrenaline rush in carrying out his crimes. His gruesome methods and the reason for his choice of victims were continually trying to be analyzed during his crime period by various investigators to find out his killing pattern and prevent it beforehand but then by the time they had gotten around to that, a large number of women had already fallen prey to his traps. The killer was captured at last but at what cost, the lives of so many young women who had to be test subjects and sacrificial lambs for the protection of those who were yet to be brutally murdered.

What made his crimes go unnoticed is the larger question that is put forward through this paper and why were his crimes one of the most difficult cases to be solved is what is being analyzed. This paper looks at how higher intellect as well as a poor family background constructed a clear path for Ted Bundy to pull off his crimes with little or no difficulty. His sick psychotic brain functioned in a pattern like no other ordinary human brain because of which his 
crime patterns were hard nuts to crack and allowed him to go about conducting new, psychotic sexual activities with the corpses or trophies that he refers to them as. Punished for his crimes he was, but what brought about these crimes in the first place is the first black dot in the life chart of Ted Bundy.

The objective of this paper is to analyze the horrifying Bundy Murders in the light of his higher intellect in conjunction with a deficient childhood which constructed the platform for Ted Bundy to perpetrate his psychotic crimes in the most spotless way possible. The analysis of this will be in accordance with an autobiographical work that discusses a comprehensive history of the murders of Ted Bundy. This autobiographical text provides detailed descriptions of the complete history behind the mad killing spree, the methods, and weapons used for carrying out those heinous crimes, the pattern of murder and the choice of victims, and most importantly the life of young Ted Bundy: the very age where matters took a drastic turn for worse and happening to have a brilliantly high IQ just provided leverage and assisted the killer in making murders a neurotic and psychotic game of hiding but never to seek.

For studying certain crime patterns of an individual, it is necessary to acquire information about the person and his background. For the purpose of my study, I will be looking into the information provided for Ted Bundy on the basis of an autobiography written on his account. The research methodology thus availed in this paper is qualitative in nature and is an autobiographical account of the serial killer, Ted Bundy.

Articles written on other serial killers express similar ideas of crime patterns and childhood behaviors which have led to the corruption of young minds which in turn led to their murderous intentions. An article written by Hayriye Elif on Serial Killers: Nature vs Nurture talks about how serial killers are naturally made killers owing to some of their horrible family backgrounds. This background can be of childhood abuse that they experienced or any other such traumatic events in their younger years. In most articles written on similar topics, the same view was seen to be very accurate as even researchers have approved of this claim. She mentions that the intention to kill or do off with someone if comes naturally to some is mostly nurtured in others because of what they encountered in their childhood. This is where the article threw the spotlight on parents or other family members because they would all be collectively responsible for shaping or even creating an identity for their children. This would mean that a part of their future was mainly shaped by the occurrences and incidents in their childhood which thereby flagged their homicidal instincts at a later age.

Other articles written on the crime patterns and choice of victims gave an insight into what would be considered as the basis for the choice of certain patterns or victims. An article by Mark Seltzer on Serial Killers (2): The Pathological Public Sphere talks about how a certain serial killer has his mark on young women who have opted for a modern form of occupation such as fashion or those who work in technological fields. According to researchers, these murders or choice of victims is largely due to wanting to not break from the conventional rules set by the society for women to be at home and do household chores or other jobs such as nursing which would bring out the femininity in them. Those who could not follow this was welcomed with the punishment of murder by these serial killers. Another article by Thomas Doherty namely Licensed to Kill: An Interview with Arthur Dong talks about his interviews with a homophobic serial killer named Arthur who took it on himself to make it a main preoccupation to murder people who are homosexuals as part of being a person of faith. This article acts as a supporting claim to this statement that serial killers adopt a certain pattern of killing depending on the twisted ideals that they either believe in or want to enforce on others. But rather than approaching them, they find it easier to wipe the person off the planet to avoid interaction and interference of human emotions. These articles therefore also gave an idea of how poor communication skills and alienation from society created the unnecessary space for these killers to advance towards their victims using physical force.

The primary text namely The Bundy Murders: A Comprehensive History by Kevin M Sullivan talks about the whole history of the psychopathic serial killer Ted Bundy who was apparently going around killing young women in the '90s. The author talks about the numerous things that contributed to Ted's choice of a serial killer lifestyle and how it came about in the first place. The autobiographical account covers everything from his broken family background to his execution in an electric chair. Sullivan talks about how Bundy had been void of emotion in a few years' time after entering college. The emotional quotient was missing in him which is what caused him to go on a killing spree and conduct such heinous crimes. In the summer of 1974, Ted had already found the love of his life Liz but was unable to dedicate himself to her alone. The dark sinister intentions of wanting to abduct women and commit sexual activities with them were also getting stronger around this time. Around this time, Ted was into wild pornography where 
female dominance over men was portrayed and where scenes of bondage kept him excited and thrilled. At a very young age, Ted was already referring to one of his class teachers as a "voluptuous disciplinarian" and was seen committing sexual activities in the storeroom inside the classroom. Being a boy with brains accompanied by good looks had already scored him a lot of female attention in class which he later on claims is why he knew girls would or could easily be fooled as long as they found the person and his acts genuine from the outside.

Before Ted had gone about murdering his victims, he was believed to be a victim himself, a person whose internal devices were malfunctioning causing zero emotional responses, and through his fractured personality from his childhood. As a child, Ted received bullying comments about his family all the time especially because he was born without a father. His mom's act of remarriage happened twice and in that period, getting used to new members around the house without falling out of place was getting more difficult. The major factor that triggered him was his stepfather Johnnie, who kept triggering him with the fact about him being fatherless. This hurt young Ted's ego and the constant need to be realized as strong and independent and nothing unlike his father who left him and his mother kept resurfacing from time to time. His family background was also quite twisted in such a manner that his grandfather was rumored to have been abusive towards animals and also had a collection of pornography which he had found out hidden in his grandfather's bedroom which was later analyzed by researchers into thinking that Ted too had inculcated the same habits of the people who lived around him at the time.

Ted Bundy's wife Liz who was always there for him was the most shocked person to learn of her husband's secretive, dark and disgusting activities behind her back. Even during his time with Liz, Ted found it extremely difficult to suppress his dark desires and was constantly in search of other women with whom he could conduct his dark activities. In the book, Sullivan mentions that during Bundy's time with Liz, he found a way to have an extramarital affair with another woman where he would take her to a hillside which he would name as their favorite spot. What the other woman did not know is that through this time that he spent with her, he was mainly scanning the area for his future predatory activities, that is, in fact searching for a place where he could dump the bodies of young women after he was done with them.

As for his choice of victims, he did not settle for prostitutes rather he settled for young dark or light longhaired women who had a middle partition hairstyle living in remote areas of the country. He usually focused on ISSN: 2456-7620 women who were attending college and those whom he described as naive since they would openly follow his invitation to his car where he would knock them down and later murder them.

What made Bundy different from the other kinds of serial killers as explained by Sullivan is that Bundy was able to plan out a whole murder then execute it that is abduct, take the victim to a remote countryside, conduct repeated acts of rape and necrophilia and dispose the body and then resume with his normal day to day activities like none of this mattered. To make sure his tracks were covered, Bundy made sure that while his victim was lying unconscious in his car he made frequent calls to his thengirlfriend Liz which would throw him off tracks if at all any suspicion regarding his whereabouts arose. Sullivan in his book writes “ Ted Bundy's contact with Liz after the murder was his way of stepping back from the crevasse of complete insanity" (118). Feeling a pang of pity or guilt over the murders he committed is not something that Bundy would feel and to not be completely submerged in his world of sexual desires, Liz was his only escape.

Psychology basically talks about two kinds of psychopaths under a list published by psychologists who study psychopathy. One is called primary psychopathy where the person is believed to have a shallow effect, interpersonal coldness, and low empathy, and the other called secondary or hostile or reactive psychopathy where the individual is associated with aggressive, impulsive, and anti-social behavior and socially deviant lifestyles. Those individuals who came under the quota of primary psychopathy seemed to have possessed traits like intelligence, high boldness, dangerous, and some kind of evil aura around them. Sullivan does identify the first few traits as very prominently observed in Bundy who had no trouble approaching several women and had already pre-planned a destination, murder weapon, costumes to change, and conversation starters as part of his masterplan. The second category too had traits that were relatable to those performed by Bundy but the more prominent ones were those that belonged to the former. A personality trait namely Agreeableness was also observed as missing in Bundy as this trait is found in those who feel concerned for the people around them. Only very few women have escaped the pangs of this monster but that was not because of his concern for them as he later explains that it was only because he could either not approve of their appearance or he did not like the idea of the woman being too bold. The very fact that Bundy knew about his own nature of behavior along with his two-sided life where he could go about living what seemed like a normal life to others is what makes the scope of study for psychopathy as 
observed in Ted Bundy more intense and what makes us tremble at the fact of someone being that vulnerable and having to beg for mercy and unwillingly be at his disposal where life is then only a matter of death at the hands of someone so wicked.

The analysis made by Sullivan covered all aspects of Bundy's life and history and moreover captured the real essence of what a real killer actually is. As per his analysis of the choice of victims, poor family background and his crime patterns in relation to his high IQ, he has been able to draw the perfect picture of a person with a mind so destabilized and disturbed which in turn led him to be America's most prolific serial killer.

Through this text, Sullivan mainly focuses on Bundy's criminal activities and his way of going about a murder and his devious plans and tools that he is equipped with for the same. The limitation of this text is that Sullivan talks about the human in Bundy more than the monster in him in such a way that his actions were mostly human and came about because of his tragic past. One cannot justify such horrendous actions of a serial killer because of his catastrophic childhood experiences and thus the author's intentions of justifying his actions is not a very acceptable position.

Many tests prove that the idea of wanting to do something horrendous comes from an early age as mentioned earlier. Repressed, angry actions that could not then be showcased arises at a much older age but by then it could have been too late to analyze the cause of the actions of an individual who has been through something bad. This is the reason why those kids and adults who show signs of aggressiveness, alienation from society and have had at least some experience of killing a pet or anything relatively close to them owing to horrible family backgrounds have to be examined because trauma once affected has the power to drive the individual to commit crimes without so much as to thinking if it's logical or legal to do so. Hence a further scope for this research paper could be in analyzing the family background of serial killers in which genetics plays a role in determining what characteristics of the family member will be passed on to the child in their younger years.

\section{REFERENCES}

[1] Primary Text The Bundy Murders: A Comprehensive History

[2] Sullivan, Kevin M. The Bundy Murders:A Comprehensive History McFarland and Company, 1955.

[3] Doherty, Thomas, et al. "Licensed to Kill: An Interview with Arthur Dong" Cincaste, 1997
[4] Fisher, Joseph C. Killer Among Us: Public Reactions to Serial Murder Praeger, 1997

[5] Kendall, Elizabeth. The Phantom Prince: My Life with Ted Bundy Seattle, Madrona, 1981

[6] Seltzer, Mark "Serial Killers (2) : the Pathological Public Sphere " Critical Inquiry, 1995

[7] Winne, Steve and David Merell. Ted Bundy: The Killer Next Door. Bantam Books, 1980 